\title{
Verifying Indigenous based-claims to forest rights using image interpretation and spatial analysis: a case study in Gunung Lumut Protection Forest, East Kalimantan, Indonesia
}

\author{
Hunggul Y. S. H. Nugroho $(\mathbb{D} \cdot$ Andrew Skidmore $\cdot$ Yousif A. Hussin
}

Published online: 23 July 2020

(C) The Author(s) 2020

\begin{abstract}
The decision of Indonesian's constitutional court in May 2013, to review Law Number 41/1999 on Forestry, marked a significant step forward in Indonesian policy related to recognition of the rights of Indigenous people to forest. Under the decision, Indigenous forest is no longer considered State forest and rights to it should be granted to Indigenous communities inhabiting them as long as there is proof of their Indigenous status. However, at the implementation level, special measures are required to ascertain who is truly Indigenous. Bogus claims of indigeneity and rights to land are not uncommon. This paper examines the verification mechanism employed for spatial analysis to assess traditional knowledge and Indigenous law implementation as substantial evidences for Indigenous rights recognition to a forest area. We conducted a case study in the Gunung Lumut
\end{abstract}

H. Y. S. H. Nugroho $(\bowtie) \cdot$ A. Skidmore · Y. A. Hussin Department of Natural Resources, Faculty of GeoInformation Science and Earth Observation, University of Twente, PO Box 217, 7500 AE Enschede, The

Netherlands

e-mail: hunggulys@yahoo.com

A. Skidmore

e-mail: a.k.skidmore@utwente.nl

Y. A. Hussin

e-mail: y.a.hussin@utwente.nl

H. Y. S. H. Nugroho

BP2LHK Makassar, Jl. P. Kemerdekaan Km. 16, 5

Sudiang, Makassar, South Sulawesi 90243, Indonesia
Protection Forest with two groups of Indigenous communities living around the forest using image interpretation and spatial analysis supported by socioeconomic and cultural analysis. We also assessed the capacity and awareness of Indigenous communities to manage their forest. This case study illustrates that in general Indigenous people apply ancestral norms, beliefs and traditional knowledge and wisdom in managing their livelihoods and daily life. Nonetheless, increasing necessities of life, better accessibility, and socio-cultural assimilation has changed the Indigenous people's behavior towards nature. Holistic approaches in transferring land rights, effective longterm engagement, and revitalization of Indigenous law in line with formal law enforcement, are among the essential measures that must be conducted systematically to ensure that the Indigenous forest remains and is sustainably managed for the benefit of the Indigenous community and the environment.

Keywords ADAT · Indigeneity · Traditional knowledge $\cdot$ Indigenous forests $\cdot$ Evidence-based policy

\section{Introduction}

For many generations, Indigenous peoples have been reputedly self-sustaining with a strong connection to 
the forest linked by norms, beliefs and traditions (Sasaoka and Laumonier 2012; Mulyoutami et al. 2009; Li et al. 2010; Arizona and Cahyadi 2013; Wachira 2010). Nevertheless, the widely accepted premise of Indigenous peoples is facing serious challenge (Kuper 2003). It remains difficult to prove who is Indigenous and who is not (Muur 2015; Nair 2006; Gauset et al. 2011; Arizona and Cahyadi 2013; Royer et al. 2015). Often, there are people who claim to be Indigenous peoples using traditional symbols, for personal gain (Linggasari 2016; Kuper 2003).

Generally, Indigenous peoples is defined as descendants of those who inhabited a country or a geographical region at the time when peoples of different cultures or ethnic origins arrived (Chao 2012). However, no formal definition has been adopted in international law (APF and OHCHR 2013; UNHR 2013). One of the most cited descriptions of the concept of the Indigenous peoples was given by Jose R. Martinez Cobo (APF and OHCHR 2013):

Indigenous communities, peoples and nations are those which, having a historical continuity with pre-invasion and pre-colonial societies that developed on their territories, consider themselves distinct from other sectors of the societies now prevailing on those territories, or parts of them. They form at present non-dominant sectors of society and are determined to preserve, develop and transmit to future generations their ancestral territories, and their ethnic identity, as the basis of their continued existence as peoples, in accordance with their own cultural patterns, social institutions and legal system.

The ILO (International Labour Organization) Convention no. 169 states that a people are considered Indigenous either: because they are descendants of those who lived in the area before colonization; or because they have maintained their own social, economic, cultural and political institutions since colonization and the establishment of new states (ILO 2003). Indigenous peoples are inheritors and practitioners of unique cultures and ways of living (UNDP 2019). The United Nations Permanent Forum on Indigenous Peoples listed three main characteristics of Indigenous peoples: (1) a strong link to territories and surrounding natural resources; (2) distinct social, economic or political systems; and
(3) distinct language, culture and beliefs (UNHR 2013).

In Indonesia, a country with 250 million people and 1128 ethnic groups, the term 'Indigenous' people is associated with different terminology such as masyarakat Adat (Indigenous community) or 'masyarakat hukum Adat (Indigenous law-abiding community), native people or isolated people. However, the term that is used in legal regulations to define Indigenous people is masyarakat hukum Adat (Indigenous lawabiding community) (PSKL 2016; KATR/BPN 2015, 2016; KEMENDAGRI 2014; KLHK 2015b). The translation of Adat to "Indigenous" by Indigenous people organization in Indonesia has to be understood as a possibility to interlink with the transnational indigeneity movements (Hauser-Schäublin 2013).

The significant step forward in the government policy regarding Indigenous rights recognition in Indonesia began on May 16, 2013, when the Indonesian Constitutional Court issued Decision 35/PUU-X/ 2012 (MK 35) in a Judicial Review of Law No. 41/1999 on Forestry written by AMAN (Alliance of Indigenous People of Indonesia). The MK 35 is an important step forward for Indigenous forest users (Myers et al. 2017). Under the Constitutional Court directive, Indigenous forests located in Indigenous territories should no longer be considered State Forests as stipulated in Law No. 41/1999 with the proviso the Indigenous community still exists and is recognized by a district regulation (Mahkamah Konstitusi Republik Indonesia 2013; KEMENDAGRI 2014). This decision has opened up new political opportunities for Indigenous people to secure territory and resources threatened by State and private interests (Astuti and McGregor 2016).

AMAN, a nationwide Indigenous people organization with more than 2000 member communities, estimated that approximately 40-70 million hectares of Indonesian State forest land should be under customary control (Myers et al. 2017; Cahyadi 2014). However, Indigenous communities are required to prove their existence supported by sufficient evidence to claim their traditional territory (Siscawati et al. 2017; Boedhihartono 2017). The Ministry of Home Affairs Regulation 52/2014, stipulates five indicators of indigeneity for official recognition of an Indigenous community: (a) history of the Indigenous community; (b) Indigenous territory; (c) Indigenous law; (d) Indigenous property relations, 
inheritance and Indigenous artifacts; and (e) a customary governance system.

Looking at the Indonesian existing rules (KATR/ BPN 2016; KEMENDAGRI 2014; KLHK 2015a; PSKL 2016), the main approach to validate and verify the existence of Indigenous peoples is still focused on a legal approach based on judicial and physical data ('admissible evidences'). There are potential discrepancies between the existence and the implementation of Indigenous law. We are concerned that the recognition process will only be an instrument for political persuasion, as mentioned by Kuper (2003), rather than being considered a tool for better forest management.

We believe that to rely merely on admissible evidences is not enough to prove the indigeneity of Indigenous people.

In Indonesia, the words 'Adat' has associated with indigeneity (Moniaga 2007). Indigeneity imply genuine connections, attachment and identification, between group and locality and thus it distinguishes "natives" from others (Merlan 2009). Li et al. (2010), define indigeneity as the permanent attachment of a group of people to a fixed area of land, in a way that marks them as culturally distinct. The government of Indonesia, through the Agrarian State Ministry Regulation 5/1999, states that customary rights would be granted to a group of people who are still bound by customary law and apply the rules in their daily living. However, Indigenous rights are susceptible to misuse, and claims to Indigenous rights should be considered on the basis of critical observations employing field research as well as historic data (Bakker 2008). In fact, nowadays political manifestations of Adat rights are no longer limited to the struggle for recognition of land rights, on the contrary, it has developed into many local, short-term “Adat projects' (van der Muur et al. 2019). There have been appearances of 'self-indigenization groups', 'an instant Indigenous community', groups of people in many regions of the world, including Indonesia, who claim indigeneity for impure motives following the broader acceptance of Indigenous people's revival discourse and the existence of supporting legal regulations (Linggasari 2016; McKenna 2016; Chavers 2014; Badan Legislasi 2017; Moeliono et al. 2010; Grumblies 2013; Couturier 2020). During our research in Paser District, East Kalimantan 2009-2015, we noticed that there was a tendency to push Adat forest mapping even though in reality these Indigenous peoples have no historical records of the boundaries of their territory. This euphoria has increased the desire of Indigenous peoples to immediately make claims to customary territories even in areas far from their present location.

Using a case study in Gunung Lumut Protection Forest (GLPF), our research aimed to assess the historical connection between indigeneity and territory. Territory is often regarded as a key aspect of indigeneity (Grydehøj and Ou 2017; Royer et al. 2015). Here we discuss an approach in the verification process of Indigenous rights to a forest territory by assessing substantial evidence to support the existing admissible evidence. Substantial evidence refers to logic and reasonable evidence obtained from adequate and well-controlled investigation to support a conclusion (Stason 1941; Coutant et al. 2011).

This approach was designed to ensure that the transfer of control rights to forest granted to a certain group of people was not merely a form of rights recognition, but also an attempt to ensure that the Indigenous forest is sustainably managed for the benefit of the Indigenous community and the environment. We employed spatial analysis supported by socio-economic and cultural analysis to examine traditional knowledge and Indigenous law implementation as substantial evidence of indigeneity, 'de facto' recognition, of Indigenous people.

We examined the capacity, capabilities and awareness of Indigenous peoples and then analyzed our data to assess whether the Indigenous people had the capacity to manage their territory sustainably. The two main questions we had to address were: (1) do they have the necessary traditional wisdom and knowledge of forest management, and (2) are they aware and committed to the implementation of Indigenous law when conducting economic activities in their forest while avoiding land degradation.

\section{Case study area}

The study was conducted in Gunung Lumut Protection Forest (GLPF), Paser District, in the southeastern part of East Kalimantan Province, Indonesia (Fig. 1). In 1983, GLPF was designated a Protection Forest (Hutan Lindung) with the main functions to serve as a life support system, and to maintain the hydrological system. Its main river, the Kandilo (181 km long), flows downstream to the flood plain in Tanah Grogot, 


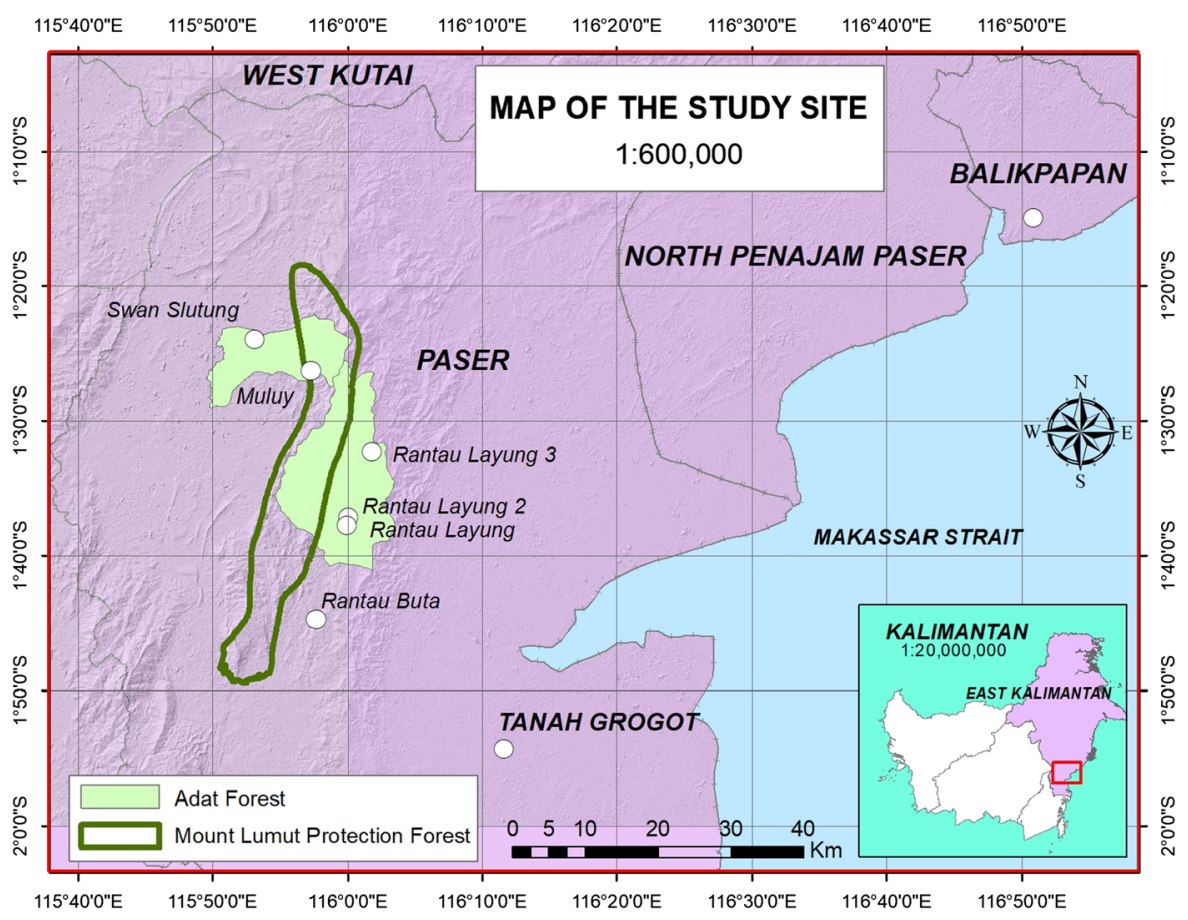

Fig. 1 Map of the study site

the capital city of Paser District. Approximately 96 million $\mathrm{m}^{3} /$ year of irrigation and domestic water, valued at US \$ 7.8 million per year, is provided by Gunung Lumut Protection Forest (Tropenbos International Indonesia 2006).

The Paser Dayak are an Indigenous people, Indigenous to Paser District, who live around Gunung Lumut. During the last two decades, organized and spontaneous migration of people from outside and inside East Kalimantan have increased the population density and ethnic diversity in the region (Wahyuni 2011). Currently, the people living in and around GLPF represent three socio-cultural backgrounds: (1) Paser Dayak, (2) Banjar people, immigrants from South Kalimantan, and (3) immigrants from outside Kalimantan, the majority of whom moved from Java and Sulawesi with the central government transmigration program. Subsistence farming with minimum inputs and outputs is the most common agricultural system in the study area. The immigrants originally practiced permanent farming systems of planting food crops (e.g., upland rice, soybeans, maize) and rubber (Nugroho et al. 2017a). We observed two communities living in forest areas representing two different cultures: (1) Muluy (an Indigenous community), and
(2) Rantau Layung (a mixed Indigenous and immigrant community). Administratively, Muluy Village comes under the jurisdiction of Swan Slutung Village, the subdistrict of Muara Komam. Rantau Layung Village is located in the subdistrict of Batu Sopang. The present settlement of Muluy is more accessible than Rantau Layung. Muluy is accessible by car the whole year, while Rantau Layung can only be reached by boat during the rainy season.

The general characteristics of the villages/kampongs are presented in Table 1.

\section{Research methods}

The methods described here explore the potential of using image interpretation and spatial analysis as a source of evidences of indigeneity. Figure 2 depicts the verification process of the Adat forest (forest managed by Indigenous people) drawing together the analysis of admissible and substantial evidence. In this paper, we focus on analyzing substantial evidence, which consists of: (1) map conformity as an instrument to assess traditional knowledge, and (2) 
Table 1 General characteristics of the villages in the study area

\begin{tabular}{llll}
\hline Villages & $\begin{array}{l}\text { Villager } \\
\text { composition }\end{array}$ & Farming system/commodity & Additional activities \\
\hline $\begin{array}{c}\text { Rantau } \\
\text { Layung } \\
\text { Muluy }\end{array}$ & $\begin{array}{c}\text { Dayak Paser and } \\
\text { Banjar } \\
\text { Dayak Paser }\end{array}$ & $\begin{array}{c}\text { Moved from shifting cultivation to permanent farming/ } \\
\text { upland rice, oil palm, rubber } \\
\text { Shifting cultivation/upland rice }\end{array}$ & $\begin{array}{c}\text { Rattan, hunter-gatherer of deer, } \\
\text { bird, honey, fruit } \\
\text { Hunter-gatherer of deer, bird, } \\
\text { honey, fruit }\end{array}$ \\
\hline
\end{tabular}

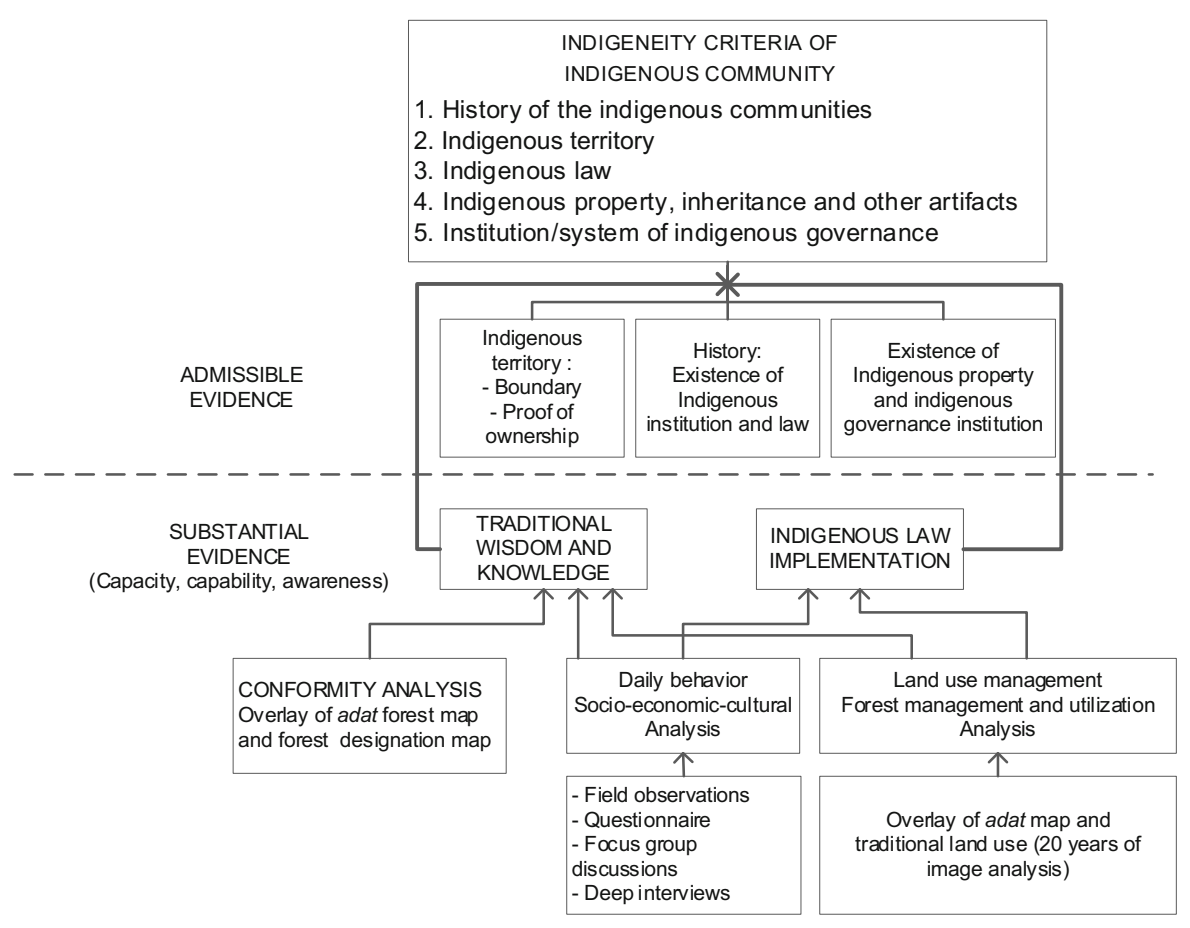

Fig. 2 Research framework

historical land-use patterns as an instrument to assess Indigenous law implementation.

We analyzed the map conformity and Indigenous land-use expansion patterns to: (1) find out whether the Indigenous people have the necessary knowledge of space management and, (2) analyze and compare traditional knowledge (Indigenous map) and scientific knowledge (forest designation map). In this paper, traditional knowledge refers to local empirical knowledge, know-how, observations over the centuries and trial and error, maintained by oral communication from generation to generation (Guidotti 2007; Martinez 2010; Mazzocchi 2006), which have evolved by adaptive processes (Mazzocchi 2006; Snively and Corsiglia 2001). In contrast to traditional knowledge, scientific knowledge utilizes technology and quantitative methodology, but may lack sufficient long-term experience on the ground in particular areas (Martinez 2010).

Conformity analysis

We conducted spatial analysis to prove whether the Adat forest zonation and designation meet the specific requirements of (conform to) scientific approach standards in land-use designation. In this case, we employed a map of the designated forest zone (a map designating provincial forest areas and inland water, coastal and marine ecosystems of East Kalimantan Province) produced by the Indonesian Ministry of 
Forestry as a comparison in the conformity analysis. The Indonesian Ministry of Forestry determined the function-based forest designation, based on degradation risk analysis using at least three criteria: slope, soil erodibility, and rainfall intensity. The conformity analysis also takes into account the restrictions of the use of forestland with slopes greater than $40 \%$ for any agricultural activities (Republik Indonesia 2008).

We assume that the capacity, capability and awareness of Indigenous peoples of sustainable forest management will be visible, among others, from the way Adat forest designation has been designed. Our hypothesis was that the zonation process of Indigenous forest has considered the biophysical conditions of the areas and been guided by traditional wisdom.

Land-use analysis

To produce land use and land cover maps, we analyzed satellite images with less than $10 \%$ cloud cover from six different years, taken at approximately four-yearly intervals between 1992-2012, using image processing software (ER-mapper 7.1 and ArcGIS 10.1). To produce an accurate classification, six annual ground checks were conducted between 2009 and 2014. We overlaid each map individually on Indigenous forest maps and slope to examine how consistently Indigenous people follow Indigenous law that regulates land allocation.

The output of this analysis provided an overview of whether the transfer of control over forests contributes to forest preservation or accelerates deforestation. In this paper, Indigenous land use refers to a combination of shifting cultivation systems of staple crops and traditional systems of rubber and oil palm plantations with very low or no external inputs and low outputs.

A socio-cultural data compilation was carried out between 2009 and 2013. In the last year of the observations (2013), although the MK 35 already existed, there were very few Indigenous people aware of the decision. Under these conditions, we assume the information would be objective in accordance with existing conditions. However, achieving accurate socio-cultural data based on direct interviews was challenging since some respondents refrained from openly discussing their 'considered-illegal' forestbased activities (Nugroho et al. 2017a). To minimize misinformation and to anticipate some inconsistent responses, especially with regard to farming systems, forest-based income generation, implementation of customary law, and the extent and location of traditional land use, we conducted a series of periodic field visits from 2009 to 2013. Data were collected through interviews using questionnaires, focus group discussions (FGD), informal meetings and dialogues with individuals, and farmland/field visits. To acquire more detailed information on specific issues, we conducted personal interviews with key respondents such as Indigenous heads and elders.

\section{Results}

Map conformity

Based on the Adat forest maps, the total community forest in Rantau Layung is about 27,300 ha, whereas the total Muluy Forest is only 13,000 ha, including PT. Telaga Mas' 4900 ha 'HTI-Trans' (integrated industrial forest plantation) concession. The Indigenous communities divide Adat forests into several functions using their own language as described in Table 2.

For the conformity analysis, we overlaid Adat forest maps on the map of the Designation of Provincial Forest Area and Inland Water, Coastal and Marine Ecosystems of East Kalimantan Province. This map divides East Kalimantan land into 4 designated areas: HPT (Hutan Produksi Terbatas/Limited Production Forest), HP (Hutan Produksi/Production Forest), HL (Hutan Lindung/Protection Forest), and APL (Area Penggunaan Lain/Non Forest Area). The conformity map is presented in Fig. 3. Tables 3 and 4 show the distribution of Adat forests based on slope class. Based on the Designation of Provincial Forest Area and Inland Water, Coastal and Marine Ecosystem of East Kalimantan Province Map, $100 \%$ of Indigenous forests of the two communities are situated in forest areas.

In Table 3, we can see that $72 \%$ of awa ngumo (Indigenous forest allocated for agricultural) is coincident with production forest and the rest of the $28 \%$ with limited production forest and protection forest, which are not designated for agricultural activities. Meanwhile, $100 \%$ of kebon (area designated for fruit trees and medicinal plants) is situated in limited production forest.

In Table 4, 100\% of awa ngumo and awa penyekulo (area designated for agriculture) of Rantau Layung as 
Table 2 The general characteristics of Indigenous forest designation

\begin{tabular}{|c|c|c|c|c|}
\hline No & $\begin{array}{l}\text { Land use/ } \\
\text { designation }\end{array}$ & Landscape characteristics & Main function & Land use \\
\hline 1 & $\begin{array}{l}\text { Strat } \\
\quad \text { (settlement } \\
\text { area) }\end{array}$ & Flat and undulating, close to road/river & $\begin{array}{l}\text { Settlement, public } \\
\text { facilities }\end{array}$ & $\begin{array}{l}\text { Communal system based on } \\
\text { Indigenous regulations, managed by } \\
\text { indigenous elders }\end{array}$ \\
\hline 2 & $\begin{array}{l}\text { Alas Adat/ } \\
\text { alas tuo }\end{array}$ & $\begin{array}{l}\text { Sloping to steep, located far from the } \\
\text { village }\end{array}$ & $\begin{array}{l}\text { Hunting area, restricted } \\
\text { areas/swidden farming } \\
\text { forbidden }\end{array}$ & $\begin{array}{l}\text { Mix of forest trees, Dipterocarpaceae } \\
\text { family, honey tree Durio sp. etc }\end{array}$ \\
\hline 3 & $\begin{array}{l}\text { Alas nareng/ } \\
\text { alas burok }\end{array}$ & $\begin{array}{l}\text { Flat to gently sloping, shifting cultivation } \\
\text { fallow area, close to the village, } \\
\text { secondary forest }\end{array}$ & $\begin{array}{l}\text { Reserved areas for } \\
\text { agricultural activities }\end{array}$ & $\begin{array}{l}\text { Secondary forest, pioneer trees, } \\
\text { shrubs }\end{array}$ \\
\hline 4 & $\begin{array}{l}\text { Awa } \\
\quad \text { pangeramu }\end{array}$ & Flat, gently sloping, steep & $\begin{array}{l}\text { Community forest for } \\
\text { fruit trees and timber }\end{array}$ & $\begin{array}{l}\text { Fruit trees, timber trees, wild pioneer } \\
\text { trees }\end{array}$ \\
\hline 5 & $\begin{array}{l}\text { Awa ngumo/ } \\
\text { umo/ } \\
\text { penyekulo }\end{array}$ & $\begin{array}{l}\text { Flat, gently sloping, steep, usually close } \\
\text { to village, river and/or road }\end{array}$ & $\begin{array}{l}\text { Shifting cultivation, } \\
\text { permanent farming }\end{array}$ & $\begin{array}{l}\text { Subsistence farming: upland rice, } \\
\text { rubber trees, oil palm }\end{array}$ \\
\hline 6 & Kebon & $\begin{array}{l}\text { Flat, gently sloping, located around the } \\
\text { house }\end{array}$ & $\begin{array}{l}\text { Fruits, vegetables, } \\
\text { medicinal plants }\end{array}$ & $\begin{array}{l}\text { No tillage, directly planted from seed } \\
\text { and/or natural seedlings }\end{array}$ \\
\hline
\end{tabular}

Source: Interview and ground checks 2012-2014, Murniati et al. (2006) and Wahyuni (2011)
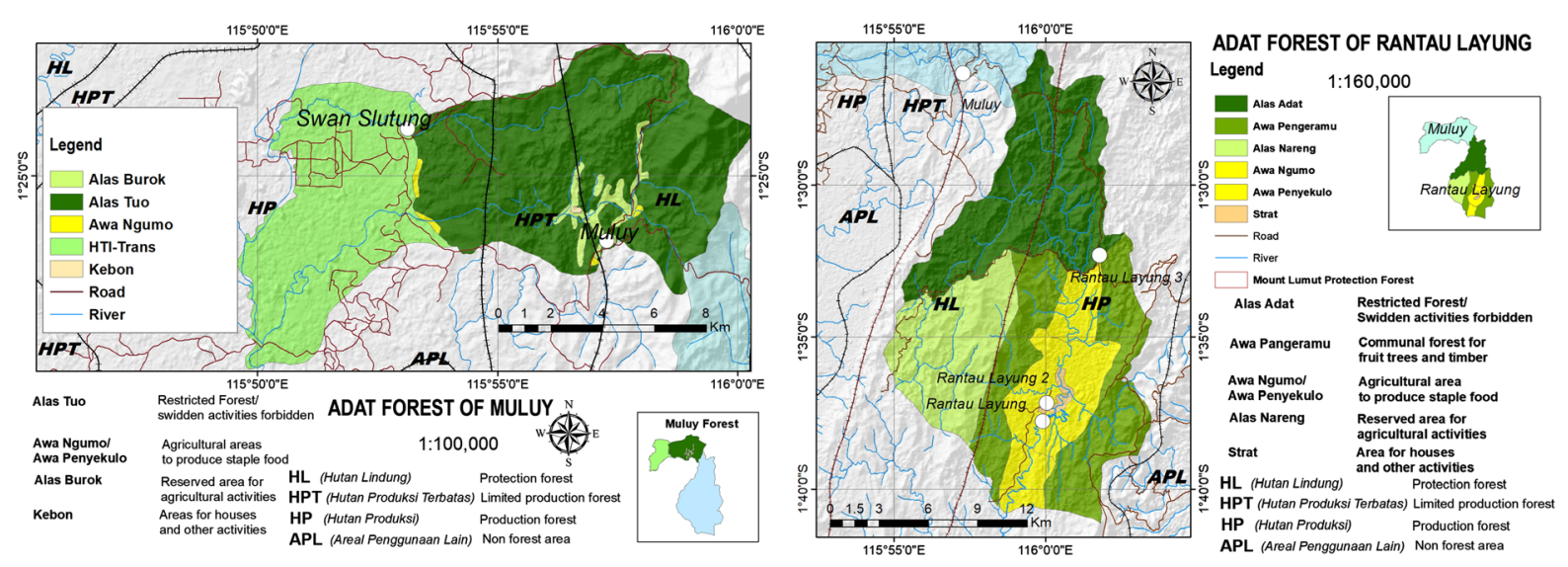

Fig. 3 Overlay of Adat forests and forest designation

Table 3 Distribution of Adat forests of Muluy based on forest designation

\begin{tabular}{|c|c|c|c|c|c|c|c|}
\hline \multirow{2}{*}{ Land use } & \multicolumn{2}{|c|}{ Production forest $(\mathrm{Ha})$} & \multicolumn{2}{|c|}{ Limited production forest $(\mathrm{Ha})$} & \multicolumn{2}{|c|}{ Protection forest } & \multirow{2}{*}{$\begin{array}{l}\text { Total (Ha) } \\
\mathrm{Ha}\end{array}$} \\
\hline & $\mathrm{Ha}$ & $\%$ & $\mathrm{Ha}$ & $\%$ & $\mathrm{Ha}$ & $\%$ & \\
\hline Alas tuo & 1385 & 18 & 2096 & 28 & 4040 & 54 & 7521 \\
\hline las burok & - & - & 125 & 31 & 280 & 69 & 405 \\
\hline Awa ngumo & 54 & 72 & 8 & 11 & 13 & 17 & 75 \\
\hline Kebon & - & - & 9 & 100 & - & - & 9 \\
\hline Timber estate/transmigration & 4938 & 100 & - & - & - & - & 4938 \\
\hline Total & 6377 & 49 & 2238 & 17 & 4333 & 33 & 12,948 \\
\hline
\end{tabular}

Bold value indicates cultivation land in an area based on government regulations is not intended for agriculture 
Table 4 Distribution of Adat forests of Rantau Layung based on forest designation

\begin{tabular}{|c|c|c|c|c|c|c|c|}
\hline \multirow[t]{2}{*}{ Land use } & \multicolumn{2}{|c|}{ Production forest } & \multicolumn{2}{|c|}{ Limited production forest } & \multicolumn{2}{|c|}{ Protection forest } & \multirow[t]{2}{*}{ Total $(\mathrm{Ha}) \mathrm{Ha}$} \\
\hline & $\mathrm{Ha}$ & $\%$ & Ha & $\%$ & $\mathrm{Ha}$ & $\%$ & \\
\hline Alas Adat & 3882 & 43 & - & - & 5045 & 57 & 8927 \\
\hline Awa pangeramu & 7234 & 97 & - & - & 223 & 3 & 7457 \\
\hline Alas nareng & 167 & 3 & - & - & 5261 & 97 & 5428 \\
\hline Awa penyekulo/Awa ngumo & 5225 & 100 & - & - & - & - & 5225 \\
\hline Straat & 233 & 100 & - & - & - & - & 233 \\
\hline Total & 16,741 & 61 & - & - & 10,529 & 39 & 27,270 \\
\hline
\end{tabular}

Bold value indicates cultivation land in an area based on government regulations is not intended for agriculture

well as Straat (area designated for settlement and public facilities) are coincident with production forest. The $97 \%$ of alas nareng (reserved area for agricultural activities) is situated in forest the Ministry of Forestry has designated as protection forest.

In both communities, agricultural areas (awa ngumo, awa penyekulo, kebon) are located in areas with a slope less than $40 \%$ (Fig. 4, Tables 5 and 6). Similarly, the area reserved for agricultural activities

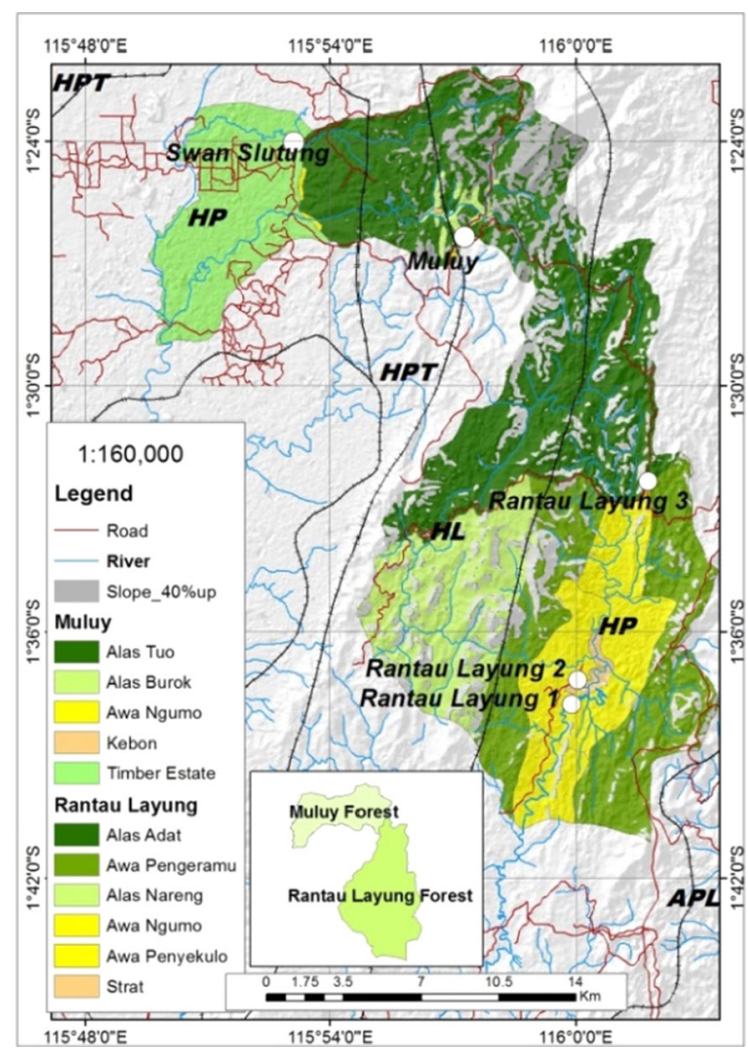

Fig. 4 Indigenous forest and slope above $40 \%$ (awa burok, awa nareng) are generally on a slope of less than $40 \%$.

Indigenous land-use

Historically, the Indigenous communities around GLPF consider the forest as the mother of life, which protects them from hunger and supplies them with everything they need. They combine swidden agriculture and forest products as the basis for their livelihoods. Hunting, gathering, and fishing are their secondary or supplementary food sources and sources of cash income. In Muluy, the revenues earned from non-timber forest products (rattan, honey, birds, wild meat) are their only sources of cash to buy consumer goods (food, clothing, motorcycles, electrical goods, furniture etc.).

For their daily food, Rantau Layung and Muluy people cultivate primarily upland rice in shifting cultivation systems applying very low amounts of fertilizer, herbicides and other agro chemical inputs. Traditionally, land parcels were 1-3 hectares per parcel, constant from year to year, which provided insufficient yields per year for their consumption. The minimal use of production inputs has resulted in relatively low agricultural outputs compared to existing standards. Rice production, equal to $107 \mathrm{~kg} / \mathrm{cap}-$ ita/year, is under the optimum standard of living in Indonesia which is equivalent to 1 ton of rice/capita/ year (Kementerian Negara Lingkungan Hidup 2014). Only relying on low quality seedlings, minimum fertilizers and limited capacity in pest control, the annual net average production of upland rice, oil palm, and rubber were $0.6,3.6$ and 0.48 tons/ha respectively between 2010 and 2011 (Nugroho et al. 2017a). This is 
Table 5 Distribution of Adat forest of Muluy based on slope class

Bold value indicates cultivation land in an area based on government regulations is not intended for agriculture

\begin{tabular}{|c|c|c|c|c|c|c|c|c|c|c|}
\hline \multirow[t]{3}{*}{ Slope $\left(^{\circ}\right)$} & \multicolumn{10}{|c|}{ Land use } \\
\hline & \multicolumn{2}{|c|}{ Alas Tио } & \multicolumn{2}{|c|}{ Alas Burok } & \multicolumn{2}{|c|}{ Awa Ngumo } & \multicolumn{2}{|c|}{ Kebon } & \multicolumn{2}{|c|}{ Timber estate } \\
\hline & $\mathrm{Ha}$ & $\%$ & $\mathrm{Ha}$ & $\%$ & $\mathrm{Ha}$ & $\%$ & $\mathrm{Ha}$ & $\%$ & $\mathrm{Ha}$ & $\%$ \\
\hline $0-10$ & 822 & 12 & 64 & 17 & 22 & 29 & 4 & 40 & 4436 & 90 \\
\hline $10-20$ & 2137 & 31 & 141 & 37 & 33 & 44 & 5 & 50 & 483 & 10 \\
\hline $20-30$ & 1827 & 26 & 95 & 25 & 15 & 20 & 1 & 10 & 18 & 0 \\
\hline $30-40$ & 1234 & 18 & 47 & 12 & 3 & 4 & & 0 & 1 & 0 \\
\hline $40-50$ & 622 & 9 & 19 & 5 & 1 & 1 & & $\mathbf{0}$ & & $\mathbf{0}$ \\
\hline $50-60$ & 249 & 4 & 11 & 3 & 1 & 1 & & $\mathbf{0}$ & & $\mathbf{0}$ \\
\hline$>60$ & 92 & 1 & 4 & 1 & & $\mathbf{0}$ & & $\mathbf{0}$ & & $\mathbf{0}$ \\
\hline Total & 6983 & 100 & 381 & 100 & 75 & 100 & 10 & 100 & 4938 & 100 \\
\hline
\end{tabular}

Table 6 Distribution of Adat forest of Rantau Layung based on slope class

\begin{tabular}{|c|c|c|c|c|c|c|c|c|c|c|}
\hline \multirow[t]{3}{*}{ Slope $\left(^{\circ}\right)$} & \multicolumn{10}{|c|}{ Land use } \\
\hline & \multicolumn{2}{|c|}{ Alas Adat } & \multicolumn{2}{|c|}{ Awa Pangeramu } & \multicolumn{2}{|c|}{ Awa Nareng } & \multicolumn{2}{|c|}{ Awa penyekulo/Awa Ngumo } & \multicolumn{2}{|c|}{ Straat } \\
\hline & $\mathrm{Ha}$ & $\%$ & Ha & $\%$ & На & $\mathrm{Ha}$ & $\%$ & Ha & $\%$ & На \\
\hline $0-10$ & 1045 & 13 & 972 & 18 & 702 & 13 & 2171 & 42 & 187 & 80 \\
\hline 10-20 & 2221 & 27 & 1658 & 32 & 1376 & 25 & 1880 & 37 & 33 & 14 \\
\hline $20-30$ & 2287 & 28 & 1289 & 25 & 1481 & 27 & 778 & 15 & 13 & 6 \\
\hline $30-40$ & 1575 & 19 & 827 & 16 & 1092 & 20 & 246 & 5 & 1 & 0 \\
\hline $40-50$ & 787 & 10 & 326 & 6 & 542 & 10 & 59 & 1 & & 0 \\
\hline $50-60$ & 263 & 3 & 115 & 2 & 178 & 3 & 3 & O & & $\mathbf{0}$ \\
\hline$>60$ & 76 & 1 & 73 & 1 & 57 & 1 & & 0 & & 0 \\
\hline Total & 8254 & 100 & 5260 & 100 & 5428 & 100 & 5137 & 100 & 234 & 100 \\
\hline
\end{tabular}

Bold value indicates cultivation land in an area based on government regulations is not intended for agriculture

low compared to the annual district productivity levels of $2.9,14$, and 1.4 tons/ha in the same period (BPS Kabupaten Pasir 2011).

Upland rice was planted for two to three seasons (2-3 years) followed by an average of 10 years fallow. After 3 years, when productivity declined, farmers moved to regenerated secondary forest, their previous fallow sites, and cleared them using slash and burn methods. According to villagers from Muluy and Rantau Layung, the successive phases of regeneration, from swidden fields to primary forest, may take more than thirty years.

Currently, Rantau Layung people live in the area along the Kandilo River where they have good means of transportation and a source of food and water. The name Rantau Layung means 'straight river' (rantau) with many lahung or layung trees (Durio sp.) in the area. Historically, their access to market was only possible when the rivers were high enough to allow transport by boat. During our research, there was road access by car in the dry season, connecting the village to the main road (logging road).

The current Muluy settlement, settled in 2001, is situated in the middle of GLPF on the roadside of the logging road that passes through GLPF, $6 \mathrm{~km}$ from Swan Slutung Village, the previous settlement of the Muluy people. Originally, the Muluy people were nomadic; they lived separately near their agricultural fields. After 2-3 years, settlements were abandoned as part of the traditional swidden agricultural system. They often moved to a new place to find good agricultural land and forest products (Murniati et al. 2006). In recent history, the pattern of movement has been influenced by family disputes, civil insurgency, 
transmigration, large-scale logging and road construction (Wahyuni 2011). In 1993, the regional government moved 22 families to Swan Slutung as part of the transmigration program.

In Rantau Layung and Muluy, apart from State law, Indigenous law is applied in daily life as traditional guidelines and rules to define what is right or wrong, what can be done and what is forbidden for the whole community. The planting season; the best time to start land clearing, ploughing and planting, in which areas, and how large an area can be utilized per household, and which trees are forbidden to cut, are all guided by Indigenous regulations and beliefs. In Muluy as well as Rantau Layung, it is prohibited to cut down honey trees (Koompassia malaccensis/Kempas) and to disturb an area dominated by ironwood trees (Eusideroxylon zwageri/Ulin) (Wahyuni 2011; Murniati et al. 2006). The Indigenous people may only use the forest area in Muluy or Rantau Layung with community permission granted in a community meeting. Based on Indigenous rule, to cut and sell timber from the forest is forbidden for inhabitants and outsiders. The Indigenous people of both communities believe that any actions against the Indigenous law will result in disaster for the transgressor/s who will have to pay a fine to the Indigenous council. The outsiders and immigrants are forbidden to open forests for rubber or oil palm plantations unless they buy from the Indigenous people or through marriage.

During our research, the villagers of Rantau Layung had already generated a cash income selling products from industrial crops (fresh fruit bunches of oil palm and rubber) and cash crops (durian, candle nut, vegetables). In contrast, the Muluy people still depended on forest products such as fruits, honey, rattan, and wild meat for cash.

We analyzed the spatial distribution of Indigenous land use from 1992 to 2012 based on the interpretation of landsat images from six different years. The spatial distribution of Indigenous land-use expansion for the period 1992 to 2012, for Muluy and Rantau Layung, is illustrated in Figs. 5 and 6. Tables 7 and 8 show the extent of the expansion based on location.

In Tables 7 and 8 we can see that traditional landuse expansion decreases in all Adat forest areas but increases outside the customary area.

To analyze Indigenous land-use expansion in Muluy, we used land-use images from 1996 as a starting image for the analysis. From 1996 to 2012,
Indigenous land use in Muluy increased from 118 to 279 ha at a rate of $6 \%$ per year (Table 7). At the end of 1990s they started to move out of their Indigenous forest and opened new land along logging roads. In 2012, $40 \%$ of these 279 ha were in alas tuo, $19 \%$ reopened fallow land (alas burok), and 37\% inside GLPF, outside their territory. Based on land slope, $3.5 \%(10 \mathrm{Ha})$ of their agricultural land was situated in an area with a slope greater than $40 \%$, in which $2.5 \%$ was located in alas ADAT and alas burok and the other $1 \%$ was close to the road outside their territory. Meanwhile, in Rantau Layung, from 1992 to 2012, Indigenous land use increased from 248 to 930 ha at a rate of $7 \%$ per year (Table 8 ). In general, their agricultural area $(67 \%)$ was situated in awa ngumo and awa penyekulo, areas designated for agriculture activities. These areas were cultivated for staple food production such as upland rice, cassava, maize, and for cash crops (candle nut, banana) as well as industrial crops (oil palm and rubber). In 2010, several people from Rantau Layung moved to alas ADAT land close to the logging road but far from their original village to open new land for oil palm. In 2012, almost $90 \%$ of Indigenous land use was situated in areas designated for agriculture (awa ngumo, penyekulo, and straat), and less than $8 \%$ was in alas ADAT. However, $3 \%$ was outside their territory. Based on land slope, there were 5 ha of agricultural land $(0.5 \%)$ situated in an area with a slope greater than $40 \%$.

Traditional land use in Muluy and Rantau Layung in 2012 are presented in Fig. 7

The major difference between Muluy and Rantau Layung is the extent and level of permanent farming. The people of Muluy have not yet adopted intensified, permanent farming as the people of Rantau Layung have. In Rantau Layung, the farmers, especially the immigrants, have developed productive industrial crops (oil palm and rubber) and cash crops such as vegetables, bananas, and other fruit trees using agriculture inputs. The immigrants extended their agricultural area by buying from other farmers especially the Indigenous people. In contrast to the Indigenous people, the immigrants had intensified farming systems of planting food crops (e.g., upland rice, soybeans, maize) and industrial crops (rubber and oil palm). However, immigrant and Indigenous communities do exchange knowledge of their farming systems. 

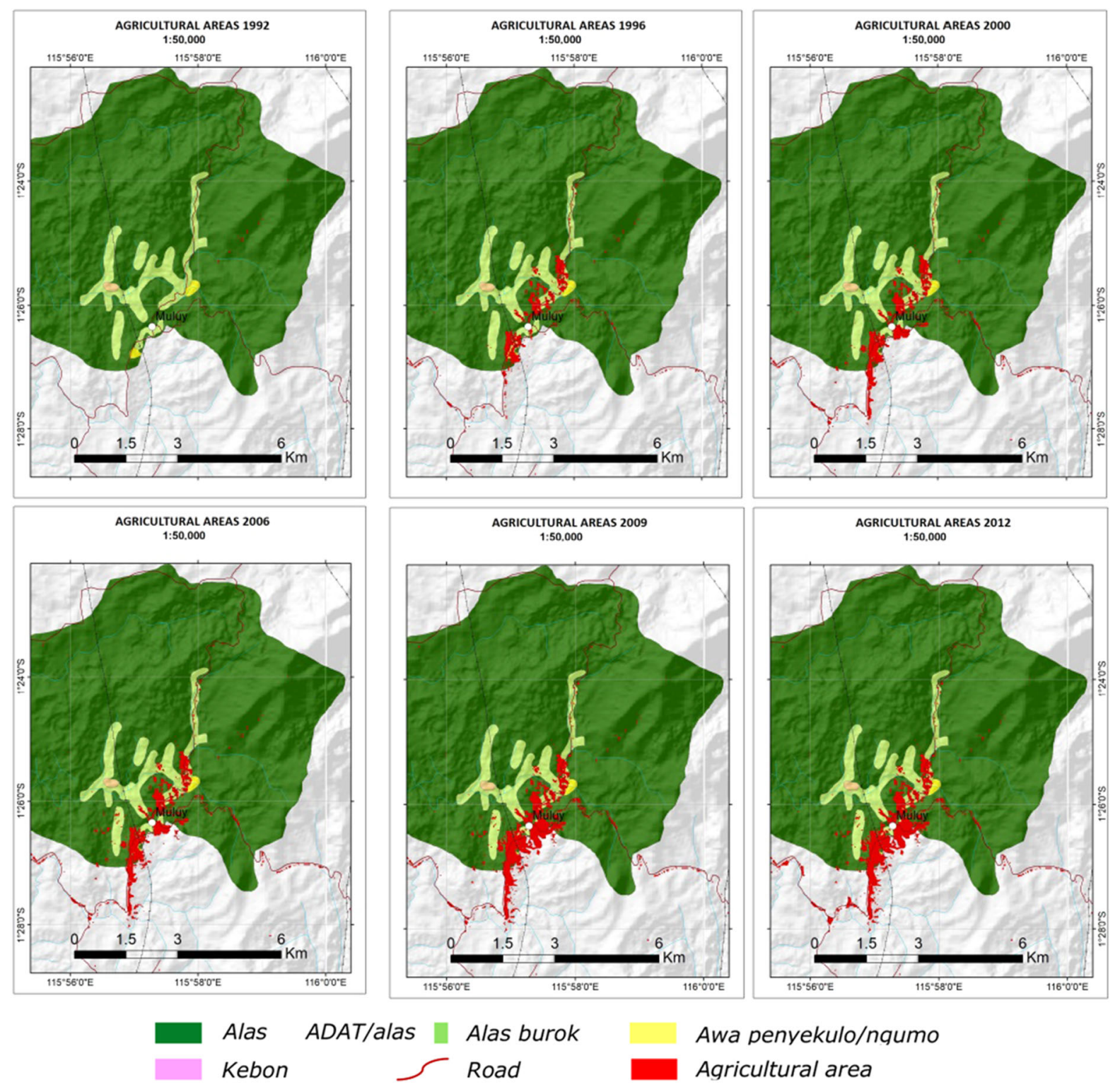

Fig. 5 Spatial distribution of changes of Indigenous land use in Muluy for the period 1992-2012

Based on the results of the spatial analysis, as presented in Tables 5, 6, 7, and 8, including areas (alas Adat/tuo, forest areas outside their territory) that should not have been cultivated, we have calculated when the existing agricultural areas of Muluy and Rantau Layung will be exhausted (Table 9).

\section{Discussion}

Traditional knowledge, distinct culture and beliefs, value systems and law, myths, strong links to territories and surrounding natural resources are considered to be the true characteristics of Indigenous people (Kementerian PPN/BAPPENAS 2013; Juanwen et al. 2012; Kawharu 2011). The question is, are all those 'distinct characteristics' reflected in their attitude and behavior. 

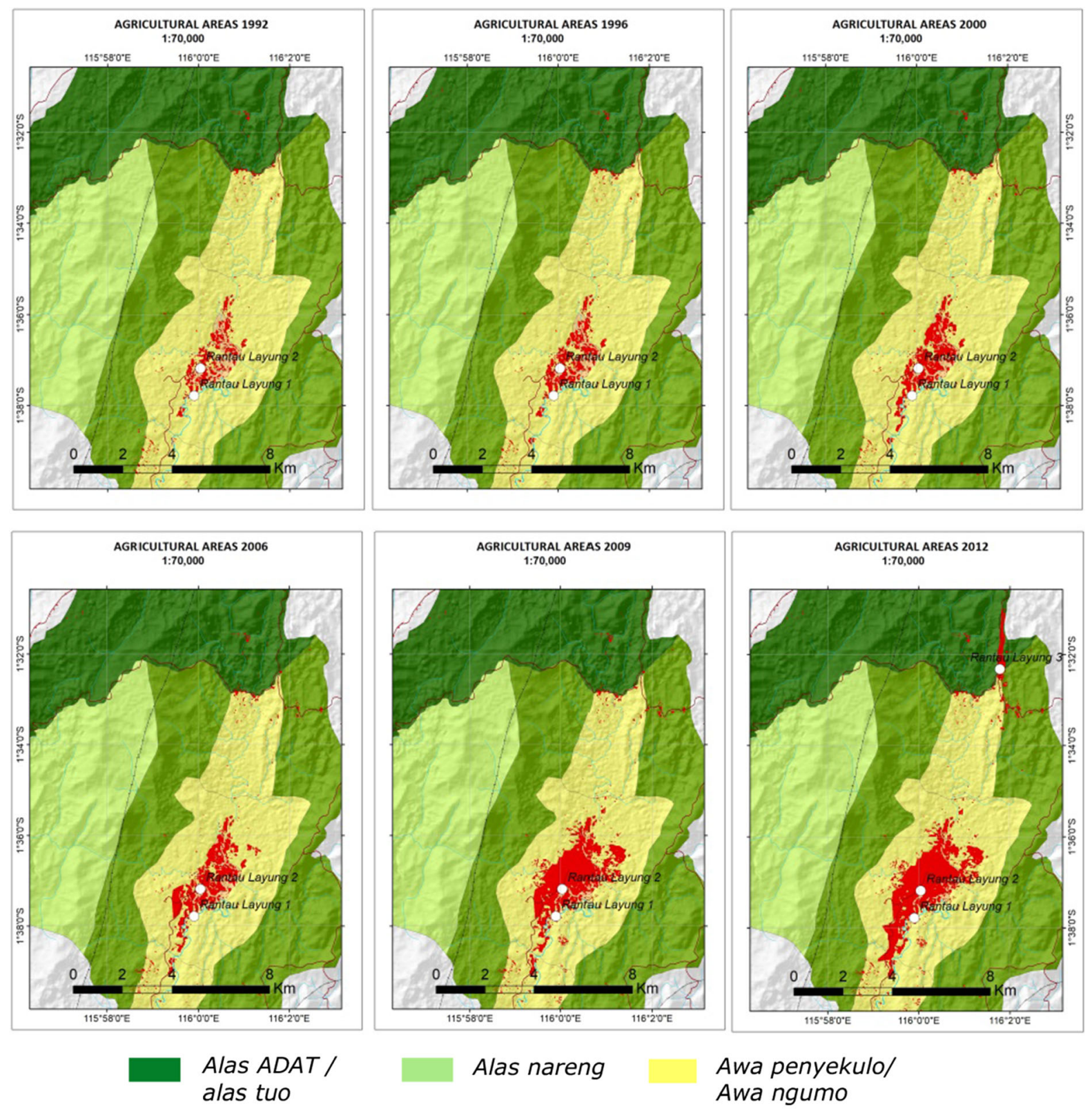

Alas nareng

Awa penyekulo/
Awa ngumo

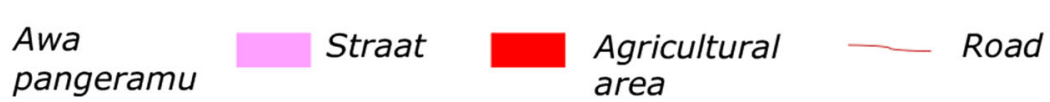

Fig. 6 Spatial distribution of changes of Indigenous land use in Rantau Layung from 1992-2012

The ancestors of the Muluy and Rantau Layung communities determined a function-based land distribution long ago. However, the boundaries were not written down. In the early 2000s the Indigenous people, with local NGO assistance, produced maps of the area. From interpretations of the Indigenous maps (Fig. 3), supported by a series of field visits, we concluded that in general the Indigenous people have traditional knowledge to manage their forests.

Overlaying the Indigenous forest maps and forest designation maps, we can see that the function-based land distribution of the Indigenous territories of both communities are in line with the criteria for land determination of the Ministry of Environment and 
Table 7 Trends in Indigenous land-use expansion in Muluy from 1992 to 2012

\begin{tabular}{|c|c|c|c|c|c|c|c|c|c|c|c|c|c|}
\hline \multirow[t]{3}{*}{ Location } & \multicolumn{12}{|c|}{ Indigenous land-use expansion } & \multirow[t]{3}{*}{20 years growth rate $(\%)$} \\
\hline & \multicolumn{2}{|l|}{1992} & \multicolumn{2}{|c|}{1996} & \multicolumn{2}{|l|}{2000} & \multicolumn{2}{|c|}{2006} & \multicolumn{2}{|l|}{2009} & \multicolumn{2}{|c|}{2012} & \\
\hline & (ha) & $\%$ & (ha) & $\%$ & (ha) & $\%$ & (ha) & $\%$ & (ha) & $\%$ & (ha) & $\%$ & \\
\hline Alas Indigenous & 2 & 100 & 53 & 45 & 72 & 42 & 81 & 42 & 107 & 41 & 111 & 40 & 5 \\
\hline Awa pangeramu & 0 & 0 & 38 & 32 & 43 & 25 & 45 & 23 & 54 & 21 & 54 & 19 & 2 \\
\hline Awa penyekulo/Ngumo & 0 & 0 & 8 & 7 & 10 & 6 & 10 & 5 & 11 & 4 & 11 & 4 & 2 \\
\hline Straat & 0 & 0 & 0 & 0 & 0 & 0 & 0 & 0 & 0 & 0 & 0 & 0 & 0 \\
\hline Outside the territory & $\mathbf{0}$ & $\mathbf{0}$ & 19 & 16 & 47 & 27 & 57 & 30 & 88 & 34 & 103 & 37 & 12 \\
\hline Total & 2 & 100 & 118 & 100 & 172 & 100 & 193 & 100 & 260 & 100 & 279 & 100 & 6 \\
\hline Growth rate & & & & 177 & & 10 & & 2 & & 10 & & 2 & \\
\hline
\end{tabular}

Table 8 Trends in Indigenous land-use expansion in Rantau Layung from 1992to 2012

\begin{tabular}{|c|c|c|c|c|c|c|c|c|c|c|c|c|c|}
\hline \multirow[t]{3}{*}{ Location } & \multicolumn{12}{|c|}{ Indigenous land-use expansion } & \multirow[t]{3}{*}{20 years growth rate $(\%)$} \\
\hline & \multicolumn{2}{|l|}{1992} & \multicolumn{2}{|c|}{1996} & \multicolumn{2}{|c|}{2000} & \multicolumn{2}{|c|}{2006} & \multicolumn{2}{|c|}{2009} & \multicolumn{2}{|c|}{2012} & \\
\hline & (ha) & $\%$ & (ha) & $\%$ & (ha) & $\%$ & (ha) & $\%$ & (ha) & $\%$ & (ha) & $\%$ & \\
\hline Alas Adat & 10 & 4 & 12 & 4 & 12 & 3 & 12 & 2 & 12 & 2 & 61 & 7 & 10 \\
\hline Awa pangeramu & 3 & 1 & 4 & 1 & 10 & 2 & 13 & 2 & 16 & 2 & 30 & 3 & 13 \\
\hline Awa penyekulo/Ngumo & 141 & 57 & 164 & 54 & 224 & 55 & 540 & 75 & 540 & 70 & 622 & 67 & 8 \\
\hline Straat & 83 & 33 & 113 & 37 & 147 & 36 & 148 & 20 & 182 & 24 & 191 & 21 & 4 \\
\hline Outside the territory & 11 & 4 & 11 & 4 & 11 & 3 & 11 & 2 & 18 & 2 & 26 & 3 & 2 \\
\hline Total & 248 & 100 & 304 & 100 & 404 & 100 & 724 & 100 & 768 & 100 & 930 & 100 & 7 \\
\hline Growth rate & & & & 5 & & 7 & & 10 & & 2 & & 7 & \\
\hline
\end{tabular}

Forestry. In Rantau Layung the awa ngumo, awa penyekulo, and awa pengeramu areas of the village are situated in production forest. Alas Adat and alas nareng areas are situated in protection forests and production forests. The Muluy community moved to what is now the core of GLPF, around 1900, long before the area was designated production forest (in 1983), awa penyekulo, kebon and alas burok, which are mostly located on gentle slopes, are now situated in protection forest. Based on our analysis of the potential risks of degradation associated with land use, we found that Indigenous forest designation maps, in both communities, correspond to the government regulations concerning forestry and spatial planning (Republik Indonesia 2008, 1999). In both, the land area with a slope greater than $40 \%$ is designated as protection areas.
The Indigenous people have accepted and worked with their traditional knowledge for many generations. However, there are global concerns that due to consumerism and short-term economic considerations, wisdom, norms and values of the Indigenous communities may be slowly eroded (Kothari 2007; Huntington et al. 2004; Samho and Purwadi 2016). From Indigenous land-use expansion patterns from 1992 to 2012, we found that the need for cash has changed the behavior of villagers towards nature, including that of the Indigenous people. Following the road construction and a boom in industrial tree production (rubber and oil palm) in the early 2000s, there was a change in the social condition of the community around GLPF (Nugroho et al. 2017a; Murniati et al. 2006; Wahyuni 2011). Farmers in Rantau Layung as well as Muluy started to cultivate 

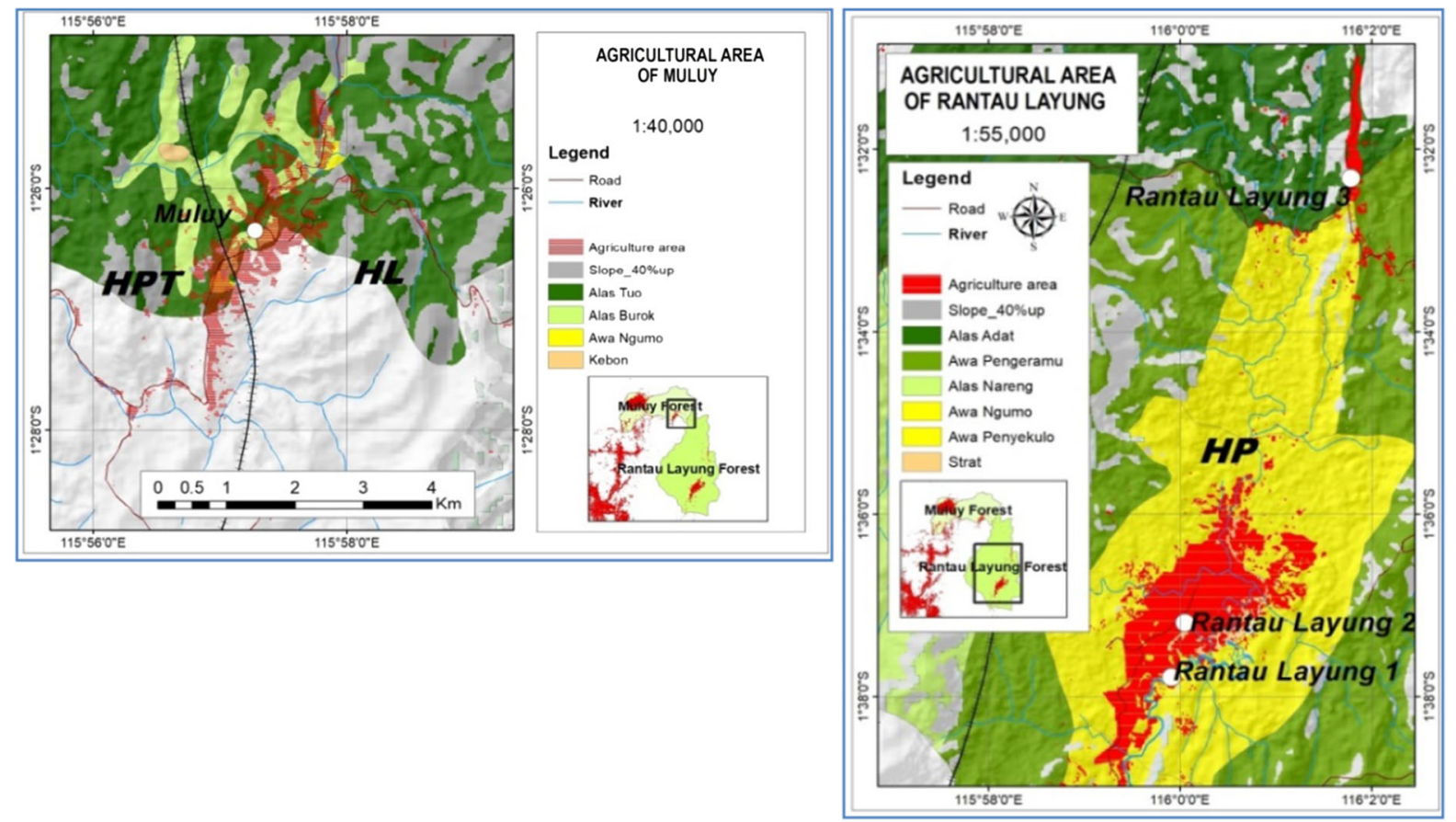

Fig. 7 Traditional land use in Muluy and Rantau Layung 2012

Table 9 Predicted time remaining

\begin{tabular}{|c|c|c|c|c|c|c|c|}
\hline \multirow[t]{2}{*}{ Land allocation } & \multicolumn{4}{|c|}{ Agricutural area $(\mathrm{Ha})$} & \multicolumn{2}{|c|}{$\begin{array}{l}\text { Existing indigenous land } \\
\text { use }\end{array}$} & \multirow[t]{2}{*}{$\begin{array}{l}\text { Remaining time*) } \\
\text { (years) }\end{array}$} \\
\hline & Total & $<40 \%$ & $\begin{array}{l}\text { Utilized } \\
\text { area }\end{array}$ & $\begin{array}{l}\text { Unutilized } \\
\text { area } \\
(\mathrm{Pt})\end{array}$ & $\begin{array}{l}\text { Area } \\
(\mathrm{Ha}) \\
(\mathrm{Po})\end{array}$ & $\begin{array}{l}\text { Growth rate } \\
(\%) \\
(\mathrm{r})\end{array}$ & \\
\hline \multicolumn{8}{|l|}{ Muluy } \\
\hline Alas burok & 381 & 347 & 54 & 293 & & & \\
\hline Awa ngumo & 75 & 73 & 11 & 62 & & & \\
\hline Total & 456 & 420 & 65 & 355 & 279 & 6 & 5 \\
\hline \multicolumn{8}{|l|}{ Rantau Layung } \\
\hline Alas nareng & 5428 & 4651 & 0 & 4651 & & & \\
\hline $\begin{array}{l}\text { Awa Penyekulo/ } \\
\text { Ngumo }\end{array}$ & 5137 & 5075 & 622 & 4453 & & & \\
\hline Total & 10,565 & 9726 & 622 & 9104 & 930 & 7 & 35 \\
\hline
\end{tabular}

*Calculation formula: $\sqrt[t]{P t}=P o(1+r)$

industrial crops. Many farmers have started to cultivate rubber or oil palm crops intercropped with upland rice. After 3 years, when the rubber/oil palm canopies block the sun and the rice cannot grow, they start to clear new land for another plantation of mixed crops.
They will not return to the land after 15 years, as they would with fallow, due to the presence of the rubber and oil palm. Thus each household must cut and clear either primary or secondary forest, including that inside GLPF every two to three years. This situation is 
in line with the findings of several scholars. The increase in population and cultural diversity in the region, better accessibility and contact with external people with different values and attitudes has increased the need for cash and so the Indigenous people's behavior towards nature has changed (Luz et al. 2015; Muur 2015; Kothari 2007).

The expansion of the agricultural area in Muluy and Rantau Layung (Fig. 7) follows a similar pattern of opening new land close to the main road for better transportation and access to markets. The majority $(80 \%)$ of Indigenous land-use expansion was located on slopes of less than $10 \%, 17 \%$ on slopes of $10-25 \%$ and only $3 \%$ on slopes greater than $25 \%$. Our previous research confirmed the belief that the presence of a road contributes to the rapid expansion of agricultural activities (Nugroho et al. 2017a). Up to 2012, of the 279 ha of Muluy's agricultural land, 103 hectares $(37 \%)$ were situated on both sides of the road, outside the Indigenous forest area, with an average growth rate of $12 \%$ per year. In general, the Indigenous land-use expansion of Muluy started from the village and the periphery of agricultural areas expanding parcel by parcel along the roadside. Based on our interviews, their main concerns in deciding which particular locations to cultivate were distance from the village, slope and accessibility. With respect to distance to the main road, $87 \%$ of new traditional land use around GLPF was located less than $1 \mathrm{~km}$, and $12 \%$ between 1 and $2 \mathrm{~km}$ (Nugroho et al. 2017a).

It is understandable that the Muluy people wanted to expand their Indigenous land use into areas outside their territory. The 'encroached' areas were closer to the village and more accessible compared to alas burok, (reserved areas for agriculture). From Table 5, we can see that areas suitable for agricultural activities (areas with a slope less than 40\%) in Muluy were 73 ha (1\%) of awa ngumo (agricultural area) and 420 ha $(5.6 \%)$ of alas burok (reserved areas for agriculture). If divided by the number of Muluy people (128), the suitable area is only $3.3 \mathrm{ha} /$ capita. Using the existing average growth rate of Indigenous land-use expansion of $6 \%$ (Table 7), land suitable for agriculture will be exhausted within the next 5 years (Table 9). As a result, instead of moving to their existing agricultural land inside their Indigenous territory, Muluy people prefer to move out to new land along the logging road.
In Rantau Layung, areas suitable for agricultural activities were 5075 ha (21\%) of awa penyekulo/awa ngumo (agricultural area) and 4651 ha (19\%) of alas nareng (reserved areas for agriculture). If divided by the number of Rantau Layung people (226), the suitable area is $43 \mathrm{ha} /$ capita. Using the existing average growth rate of $7 \%$ (Table 8), land suitable for agriculture will be exhausted within the next 35 years (Table 9). In 2008, several people from Rantau layung moved to alas ADAT close to the logging road and far from the original village, to open 40 ha of new land for oil palm. While opening the new land they built temporary houses, which, as the number of settlers increased, became a permanent settlement.

The land suitable for agricultural activities in Rantau Layung is still large and sufficient to meet the needs of future generations. However, allocated land for agriculture in Muluy is very limited. To reduce the potential pressure on adjacent forest areas, it is necessary to restructure the management and use of the Indigenous forest of Muluy through a compensation mechanism regulated by the Ministry of Environment and Forestry. The regulation (Ministry of Environment and Forestry Regulation P.32/MenlhkSetjen/2015 on Titled Forest) concerned with this area of forestry, states that:

Forested land may be designated as titled forest with a specific function based on ecosystem considerations from the Ministry of Environment and Forestry and the approval of titled holders. If the Indigenous people object to this provision, the minister shall provide compensation and/or incentives in accordance with the regulation (article 7, point 1 and 2).

Any special measures must deal with the complex processes of the recognition and implementation of Indigenous rights together with government concerns for the sustainable management of the forest, business offers from investors, and the Indigenous people's efforts to secure their livelihoods and to exercise territorial sovereignty. Long-term engagement with the Indigenous people must be planned and implemented systematically to assist Indigenous forest management in providing sustainable benefits from the forest for all, for many generations to come. Formal law enforcement and revitalization of Indigenous law is an essential measure to be conducted in line with efforts to enhance community welfare. 
However, a transparent and trustable process is a key factor. The capacity of stakeholders involved in the process is seen here as a critical issue. Thus, building capacity and raising willingness of stakeholders responsible for policy formulation, interpretation, and implementation is essential (Nugroho et al. 2017b).

\section{Conclusion}

This paper explores one narrow, but important aspect of the complex processes in Indigenous rights recognition that has not only affected the practical implications, but also presents a challenge for the long-term success of the transfer of rights to forest and the sustainable use of Indigenous forest.

This case study illustrates that the Indigenous people living around GLPF own and apply their ancestral norms, beliefs and traditional wisdom and knowledge. Nonetheless, the increasing desires for a modern life, better accessibility and socio-cultural assimilation have changed the Indigenous people's behavior towards nature. Notwithstanding the social importance of customary land rights, the two cases used in this paper indicate that the critique of environmentalists regarding Indigenous people might be justified. We are pessimistic that a 'self-sustaining community with strong connections with nature' discourse, as an identity of Indigenous community, can be upheld for much longer. Even remote people are forced by the 'necessities of life' to convert ancestral forest into rubber and oil palm plantations to simply survive.

Relying on a legal approach based on judicial and physical data alone to prove the indigeneity of Indigenous people is not enough. Adequate, and well-controlled investigation must be employed fairly and transparently to examine the capacity, capabilities and awareness of Indigenous peoples to manage their territory sustainably.

The transfer of control rights to forest was not merely a form of transfer of ownership or political approach, but also an attempt to ensure that the Indigenous forest remains and is sustainably managed for the benefit of the Indigenous community and the environment. Holistic approaches in transferring land rights, effective long-term engagement, and revitalization of Indigenous law in line with formal law enforcement, are among the essential measures that must be conducted systematically.

Finally, the accuracy of the spatial analysis may be subject to question. Different resolutions of spatial data may produce different results. However, by combining spatial analysis, field surveys, and sociocultural analysis to assess the traditional knowledge and Indigenous law implementations, as rational as possible, we provide an overview of substantial evidence of the indigeneity as a basis for the transfer of rights to forest.

Acknowledgments This work was prepared based upon a collaborative research project between the Forestry Research and Development Agency, Tropenbos International Indonesia Program, ITC and Mulawarman University in East Kalimantan, 2008-2012, entitled "Integrating Customary Rights and Traditional Land Use into Spatial Planning: The Use of Appropriate Modelling for Decision Support Systems". No PIS. 50100020. We thank the people of Muluy and Rantau Layung for their support during our fieldwork. We are grateful to Glen Mulcahy for constructive comments for improving the language of this manuscript.

\section{Compliance with ethical standards}

Conflict of interest The authors declare that they have no conflict of interest.

Human and animal rights This article does not contain any studies involving human participants performed by any of the authors.

Open Access This article is licensed under a Creative Commons Attribution 4.0 International License, which permits use, sharing, adaptation, distribution and reproduction in any medium or format, as long as you give appropriate credit to the original author(s) and the source, provide a link to the Creative Commons licence, and indicate if changes were made. The images or other third party material in this article are included in the article's Creative Commons licence, unless indicated otherwise in a credit line to the material. If material is not included in the article's Creative Commons licence and your intended use is not permitted by statutory regulation or exceeds the permitted use, you will need to obtain permission directly from the copyright holder. To view a copy of this licence, visit http://creativecommons.org/licenses/by/4.0/.

\section{References}

APF, \& OHCHR. (2013). The United Nations declaration on the rights of Indigenous peoples (a manual for national human rights institutions). Sydney, Geneva: Asia Pacific Forum of National Human Rights Institutions and the Office of the United Nations High Commissioner for Human Rights. 
Arizona, Y., \& Cahyadi, E. (2013). The revival of Indigenous peoples: Contestations over a special legislation on Masyarakat Adat. In B. Hauser-Schäublin (Ed.), Adat and indigeneity in Indonesia culture and entitlements between heteronomy and self-ascription (vol. 7, pp. 43-62, vol. Göttingen Studies in Cultural Property). Göttingen: Göttingen University Press.7

Astuti, R., \& McGregor, A. (2016). Indigenous land claims or green grabs? Inclusions and exclusions within forest carbon politics in Indonesia. The Journal of Peasant Studies, 44(2), 445-466. https://doi.org/10.1080/03066150.2016. 1197908.

Badan Legislasi. (2017). Mempolitisir Masyarakat Adat Merusak Tatanan. https://www.dpr.go.id/berita/detail/id/ 17628/t/

Mempolitisir+Masyarakat+Adat+Merusak+Tatanan. Accessed 14 October 2017.

Bakker, L. (2008). "Can we get hak ulayat?": Land and community in Pasir and Nunukan, East Kalimantan. In $U C$ Berkeley-UCLA joint conference on Southeast Asia, "ten years after: Reformasi and new social movements in Indonesia, 1998-2008", The University of California Berkeley, California, April 25-26 2008. Centre for Southeast Asia Studies UC Berkely.

Boedhihartono, A. K. (2017). Can community forests be compatible with biodiversity conservation in Indonesia? Land, 6(21), 17. https://doi.org/10.3390/land6010021.

BPS Kabupaten Pasir. (2011). Kabupaten Pasir Dalam Angka 2011. Tanah Grogot: Badan Pusat Statistik Kabupaten Pasir.

Cahyadi, F. (2014). Pidato Sekretaris Jenderal (Sekjen) AMAN \#HKMAN2014. https://www.aman.or.id/pidato-sekretarisjenderal-sekjen-aman-hkman2014/. Accessed 16 September 2017.

Chao, S. (2012). FOREST PEOPLES: Numbers across the world. The United Kingdom: Forest Peoples Programme.

Chavers, D. (2014). 5 Fake Indians: Checking a box doesn't make you native, census data about native Americans is often misleading. https://indiancountrymedianetwork.com/ history/events/5-fake-indians-checking-a-box-doesntmake-you-native/. Accessed 14 October 2017.

Coutant, D., Riggs, D., \& Van Sant Hoffman, E. (2011). Substantial evidence: When is a single trial sufficient for approval and promotion? Drug Information Journal, 45(3), 253-263. https://doi.org/10.1177/009286151104500306.

Couturier, C. (2020). Researchers examine the growing phenomenon of "self-indigenization". https://www. universityaffairs.ca/news/news-article/researchersexamine-the-growing-phenomenon-of-selfindigenization/. Accessed 8 June 2020.

Gauset, Q., Kenrick, J., \& Gibb, R. (2011). Indigeneity and autochthony: A couple of false twins? Social Anthropology/Anthropologie Sociale, 19(2), 135-142. https://doi. org/10.1111/j.1469-8676.2011.00144.x.

Grumblies, A.-T. (2013). Being Wana, becoming an "Indigenous people". Experimenting with indigeneity in central Sulawesi. In B. Hauser-Schäublin (Ed.), Adat and indigeneity in Indonesia culture and entitlements between heteronomy and self-ascription (vol. 7, pp. 82-98, vol. Göttingen Studies in Cultural Property). Göttingen: Göttingen University Press.7
Grydehøj, A., \& Ou, Z. (2017). Deterritorialization of indigeneity: Indigenous territory, development policy, and the Dan fishing community of Hainan (China). Political Geography, 61(Supplement C), 77-87. https://doi.org/10. 1016/j.polgeo.2017.07.002.

Guidotti, T. L. (2007). Traditional knowledge: Challenge or complement to science? Archives of Environmental and Occupational Health, 62(4), 167-168. https://doi.org/10. 3200/AEOH.62.4.167-168.

Hauser-Schäublin, B. (2013). Introduction. The power of indigeneity: Reparation, readjustments and repositioning. In B. Hauser-Schäublin (Ed.), Adat and indigeneity in Indonesia culture and entitlements between heteronomy and selfascription (vol. 7, pp. 5-12, vol. Göttingen Studies in Cultural Property). Göttingen: Göttingen University Press.7

Huntington, H., Callaghan, T., Fox, S., \& Krupnik, I. (2004). Matching traditional and scientific observations to detect environmental change: A discussion on Arctic terrestrial ecosystems. Ambio, Spec No 13, 18-23.

ILO. (2003). ILO convention on Indigenous and tribal peoples, 1989 (No1.69): A manual. Geneva: Project to Promote ILO Policy on Indigenous and Tribal Peoples, International Labour Organisation.

Juanwen, Y., Quanxin, W., \& Jinlong, L. (2012). Understanding Indigenous knowledge in sustainable management of natural resources in China: Taking two villages from Guizhou Province as a case. Forest Policy and Economics, 22, 47-52. https://doi.org/10.1016/j.forpol.2012.02.012.

KATR/BPN. (2015). Tata Cara Penentuan Hak Komunal atas Tanah Masyarakat Hukum Adat dan Masyarakat yang Berada dalam Kawasan Tertentu. Peraturan Menteri Agraria dan Tata Ruang/Kepala Badan Pertanahan Nasional, Nomor 9 Tahun 2015.

KATR/BPN. (2016). Tata Cara Penetapan Hak Komunal atas Tanah Masyarakat Hukum Adat dan Masyarakat yang Berada pada Kawasan Tertentu: Peraturan Menteri Agraria dan Tata Ruang/Kepala Badan Pertanahan Nasional Nomor 10 Tahun 2016.

Kawharu, M. (2011). Forestry and Indigenous issues: New Zealand and the pacific. Paper presented at the International Expert Group Meeting Indigenous Peoples and Forests, New York, 12-14 January 2011.

KEMENDAGRI. (2014). Pedoman Pengakuan dan Perlindungan Masyarakat Hukum Adat (Berita Negara Republik Indonesia Tahun 2014 Nomor 951). Peraturan Menteri Dalam Negeri Nomor 52 tahun 2014.

KEMENDAGRI, K., PU, \& BPN. (2014). Tata Cara Penyelesaian Penguasaan Tanah yang Berada di Dalam Kawasan Hutan (Berita Negara Republik Indonesia Tahun 2014 Nomor 1.719): Peraturan Bersama Nomor: 79 Tahun 2014, PB.3/Menhut-11/2014, 17/PRT/M/2014, 8/SKB/X/2014.

Kementerian Negara Lingkungan Hidup. (2014). Pedoman Penentuan Daya Dukung dan Daya Tampung Lingkungan Hidup. Jakarta: Kementerian Negara Lingkungan Hidup Republik Indonesia.

Kementerian PPN/BAPPENAS (2013). Masyarakat Adat di Indonesia: Menuju Perlindungan Sosial yang Inklusif. Jakarta: Direktorat Perlindungan dan Kesejahteraan Masyarakat, Kementeriaan PPN/Bappenas. 
KLHK. (2015a). Hutan Hak (Berita Negara Republik Indonesia Tahun 2015 Nomor 1025): Peraturan Menteri Lingkungan Hidup dan Kehutanan Nomor P.32/Menlhk-Setjen/2015.

KLHK. (2015b). Penanganan Konflik Tenurial Kawasan Hutan (Berita Negara Republik Indonesia Tahun 2016 Nomor 165): Menteri Lingkungan Hidup dan Kehutanan Nomor P.84/Menlhk-Setjen/2015.

Kothari, A. (2007). Traditional knowledge and sustainable development. Manitoba, Canada: International Institute for Sustainable Development (IISD).

Kuper, A. (2003). The return of the native. Current Anthropology, 44(3), 389-402.

Li, T., \& Xa, \& Murray,. (2010). Indigeneity, capitalism, and the management of dispossession. Current Anthropology, 51(3), 385-414. https://doi.org/10.1086/651942.

Linggasari, Y. (2016). Pengabaian Hak Masyarakat Adat Bisa Berujung Separatisme. https://www.cnnindonesia.com/ nasional/20160124195910-20-106337/pengabaian-hakmasyarakat-Adat-bisa-berujung-separatisme/. Accessed 16 August 2017.

Luz, A., Guèze, M., Paneque-Gálvez, J., Pino, J., Macía, M., Orta-Martínez, M., et al. (2015). How does cultural change affect Indigenous peoples' hunting activity? An empirical study among the Tsimane' in the Bolivian Amazon. Conservation and Society, 13(4), 382-394. https://doi.org/10. 4103/0972-4923.179879.

Mahkamah Konstitusi Republik Indonesia. (2013). Pengujian Undang Undang 41 tahun 1999 tentang Kehutanan (20 Mei 2013 ed.): Putusan Mahkamah Konstutisi Republik Indonesia Nomor 35/PUU-X/2012.

Martinez, D. (2010). The value of Indigenous ways of knowing to western science and environmental sustainability. The Journal of Sustainability Education. http://www.susted. $\mathrm{com} /$ wordpress/content/the-value-of-indigenous-ways-ofknowing-to-western-science-andenvironmentalsustainability_2010_05/.

Mazzocchi, F. (2006). Western science and traditional knowledge: Despite their variations, different forms of knowledge can learn from each other. EMBO Reports, 7(5), 463-466. https://doi.org/10.1038/sj.embor.7400693.

MCKenna, M. (2016). Call for aboriginal identity tests to expose fake aborigines. The Australian. https://modrogorje.com/ wp-content/uploads/2016/05/Fake-Abos-MichaelMcKenna-Comments-Australian-fake-AboriginesIndigenous-Advisory-Council-certified-genealogistsWarren-Mundine-white-blackfellas-claimingAboriginality-Land-Rights-Act-1983-Nigyanni.pdf.

Merlan, F. (2009). Indigeneity global and local. Current Anthropology, 50(3), 303-333. https://doi.org/10.1086/ 597667.

Moeliono, M., Limberg, G., Minnigh, P., Mulyana, A., Indriatmoko, Y., Utomo, N. A., et al. (2010). Meretas kebuntuan: konsep dan panduan pengembangan zona khusus bagi Taman Nasional di Indonesia. Bogor, Indonesia: Center for International Forestry Research (CIFOR).

Moniaga, S. (2007). From Bumiputera to Masyarakat Adat: A long and confusing journey. In J. S. Davidson \& D. Henley (Eds.), The revival of tradition in Indonesian politics: The deployment of adat from colonialism to indigenism (pp. 275-294). London and New York: Routledge.
Mulyoutami, E., Rismawan, R., \& Joshi, L. (2009). Local knowledge and management of simpukng (forest gardens) among the Dayak people in East Kalimantan, Indonesia. Forest Ecology and Management, 257(10), 2054-2061. https://doi.org/10.1016/j.foreco.2009.01.042.

Murniati, P. M., Basuki, I., \& van der Ploeg, J. (2006). Gunung Lumut biodiversity assessment socio-economic study: How important forest and landscape resource for community living in and around Gunung Lumut protection forest? Final report to TROPENBOS. Bogor, Indonesia: Center for International Forestry Research (CIFOR).

Muur, W. V. D. (2015). Will customary land rights destroy Indonesia's last remaining forests?https://leidenlawblog. $\mathrm{nl} /$ articles/will-customary-land-rights-destroy-indonesiaslast-remaining-forests. Accessed 25 April 2015.

Myers, R., Intarini, D., Sirait, M. T., \& Maryudi, A. (2017). Claiming the forest: Inclusion and exclusion under Indonesia's "new" policy on cutomary forest. Land Use Policy, 66, 205-213. https://doi.org/10.1016/j.landusepol. 2017.04.039.

Nair, M. S. (2006). Defining indigeneity situating transnational knowledge. New Delhi.

Nugroho, H. Y. S. H., van der Veen, A., Skidmore, A. K., \& Hussin, Y. A. (2017a). Expansion of traditional land-use and deforestation: a case study of an Adat forest in the Kandilo Subwatershed, East Kalimantan, Indonesia. Journal of Forestry Research. https://doi.org/10.1007/ s11676-017-0449-9.

Nugroho, H. Y. S. H., van der Veen, A., Skidmore, A. K., \& Hussin, Y. A. (2017b). Theoretical framework for spatial planning and forest management in Indonesia: Securing the basic rights for adat people. [Forest management, adaptive governance, spatial planning, Indonesia, Adat]. Indonesian Journal of Forestry Research, 4(1), 15. https://doi.org/10. 20886/ijfr.2017.4.1.69-83.

PSKL. (2016). Tata Cara Verifikasi dan Validasi Hutan Adat. Jakarta: Direkorat Jenderal Perhutanan Sosial dan Kemitraan Lingkungan.

Republik Indonesia. (1999). Kehutanan (Lembaran Negara Republik Indonesia Tahun 1999 Nomor 167): Undang Undang Nomor 41 Tahun 1999.

Republik Indonesia. (2008). Rencana Tata Ruang Nasional (Lembaran Negara Republik Indonesia Tahun 2008 nomor 48 ). Jakarta: Peraturan Pemerintah Nomor 26 Tahun 2008.

Royer, S. D., Visser, L. E., Galudra, G., Pradhan, U., \& Noordwijk, M. V. (2015). Self-identification of Indigenous people in postindependence Indonesia: A historical analysis in the context of REDD? International Forestry Review, 17(3), 282-297. https://doi.org/10.1505/ 146554815815982648 .

Samho, B., \& Purwadi, Y. S. (2016). Perubahan Pola Pikir Masyarakat Adat Dayak di Kabupaten Sanggau terhadap Hutan Adat Sebagai Akibat Perkebunan Kelapa Sawit (Vol. Perjanjian No: III/LPPM/2016-02/115-P). Bandung: Lembaga Penelitian dan Pengabdian kepada Masyarakat, Universitas Parahyangan.

Sasaoka, M., \& Laumonier, Y. (2012). Suitability of local resource management practices based on supernatural enforcement mechanisms in the local social-cultural context. Ecology and Society, 17(4), 1-10. https://doi.org/10. 5751/ES-05124-170406. 
Siscawati, M., Banjade, M. R., Liswanti, N., Herawati, T., Mwangi, E., Wulandari, C., et al. (2017). Overview of forest tenure reforms in Indonesia (Vol. Working Paper 223, pp. 36). Bogor, Indonesia: Centre for International Forestry Research (CIFOR).

Snively, G., \& Corsiglia, J. (2001). Discovering Indigenous science: Implications for science education. Science Education, 85(1), 6-34. https://doi.org/10.1002/1098237X(200101)85:1<6:AID-SCE3>3.0.CO;2-R.

Stason, E. B. (1941). "Substantial evidence" in administrative law. University of Pennsylvania Law Review and American Law Register, 89(8), 1026-1051. https://doi.org/10.2307/ 3309074.

Tropenbos International Indonesia. (2006). Penilaian Ekonomi Sumberdaya Hutan Lindung Gunung Lumut, Kabupaten Paser, Kalimantan Timur (Vol. TE-06/TBI Indonesia/05I). Bogor, Indonesia: Tropenbos International Indonesia dan Greenomics Indonesia.

UNDP. (2019). 10 things to know about Indigenous peoples. https://stories.undp.org/10-things-we-all-should-knowabout-Indigenous-people. Accessed 9 February 2020.

UNHR. (2013). Indigenous peoples and the United Nations human rights system (Vol. Fact Sheet No. 9/Rev.2). New
York and Geneva: United Nations Human Rights, Office of The High Commisioner.

van der Muur, W., Vel, J., Fisher, M. R., \& Robinson, K. (2019). Changing indigeneity politics in Indonesia: From revival to projects. The Asia Pacific Journal of Anthropology, 20(5), 379-396. https://doi.org/10.1080/14442213.2019. 1669520.

Wachira, G. M. (2010). Applying Indigenous Peoples' Customary Law in Order to Protect their Land Rights in Africa. In G. Rose \& J. Dahl (Eds.), Development and Customary Law (pp. 6-15, vol. Indigenous Affairs). Copenhagen, Denmark: International Work Group for Indigenous Affairs.

Wahyuni, T. (2011). Can traditional forest management protect and conserve ironwood (ulin) stands? An option and approach in East Kalimantan. Leiden: University of Leiden.

Publisher's Note Springer Nature remains neutral with regard to jurisdictional claims in published maps and institutional affiliations. 